siaalisena konstruktiona, joka voidaan luoda ja jota voidaan muokata. Sara Eeva taas käsittelee artikkelissaan Jean Rhysin tekstejä ja tarkastelee valkoista toiseutta ("Others within whiteness") Rhysin kreolinaisten konstruktioissa. Rhysin romaaneissa on kahdenlaisia valkoisia: "oikeita valkoisia" ja valkoisia kreoleja, jotka ovat eurooppalaista syntyperää, mutta syntyneet ja kasvaneet Länsi-Intian saaristossa. Eeva kirjoittaa, että koloniaalisessa kontekstissa valkoisten kreolien valkoisuus on tullut kulttuurisesti näkymättömäksi, mikä on paradoksaalisesti antanut mahdollisuuden valkoisten vallan oikeuttamiseen (s. 249).

Kokoelma on kaiken kaikkiaan kattava ja monipuolinen katsaus Amerikkatutkimuksen uusiin tuuliin. Kokoelman monitieteisyys antaa uusia näkökulmia, vaikka se myös hajauttaa kokoelman linjaa. Kaikki artikkelit ovat osaltaan kiinnostavia ja erinomaisesti toteutettuja. Kokoelma tarjoaa tuoreita näkemyksiä ja mielenkiintoista luettavaa Amerikka-tutkijoille tai aihepiiristä kiinnostuneille.

\section{Tanja Sitomaniemi}

\section{Juha Rikaman vastine Kaa- rina Kolulle}

\section{Arvostettu Kollegani,}

Kiitän Sinua väitöskirjani arvostelusta Avaimen numerossa 1/2005. Monin kohdin yhdyn arviointeihisi. Huomiosi, esimerkiksi koulun kirjallisuudenopetuksen (surkeaa) tilannetta ja sen syitä koskevat, ovat yleensä tarkkanäköisiä. Muutamassa keskeisessä asiassa olen kuitenkin kanssasi eri mieltä. Haluan ne selvittää tässä, koska asialla on laajempaa periaatteellista kantavuutta, myös tulevan - toivottavasti vihdoinkin viriävän - kirjallisuudenopetuksen tutkimuksen kannalta.

Kirjoitat: "Tieto on pääosin detaljitietoa, tiedonmurenia, joista Rikama ei edes yritä rakentaa ehjää, yhtenäistä kirjallisuusdidaktiikan viitekehykseen sijoitettua järjestelmää.” Lause osoittaa, että tutkimukseni tietoteoreettinen ja metodinen ydin on jäänyt Sinulta ymmärtämättä. Lähtökohtani, jonka tuon Johdannossa (s. 12-13) painokkaasti esiin, on, että kirjallisuudenopetus on tutkimuskohteena monimääräytynyt, monen eri alueilta tulevan tekijän vaikutusaluetta, ja sellaisena tyypillinen monitieteinen tutkimuskohde. Sellaisen tutkimisessa on välttämätöntä hyödyntää eri tutkimusaloja ja niiden näkökulmia, joiden avulla voi valaista kirjallisuudenopetuksen eri osa-alueita. Esimerkiksi reseptioestetiikka tai systeemianalyysi ei näin ollen ole "ir- 
rallinen lisä”, kuten väität, vaan eräitä toisistaan riippumattomia tarkastelunäkökulmia, jotka valaisevat joitakin piirteitä kirjallisuudenopetuksen laajasta kentästä. (Tosin tutkimuksessani liian niukasti, minunkin mielestäni.) Näin saadut tulokset ovat välttämättä rajallisia, juuri noita mainitsemiasi "tiedonmurenia", mutta niiden hyvä puoli on se, että ne ansaitsevat tiedon nimen, eivät ole spekulaatiota.

Tämä lähtökohta hylkää siis ajatuksen, että koko kirjallisuudenopetuksen laaja ilmiökenttä olisi selvitettävissä kirjallisuudidaktiikka-nimisen itsenäisen tieteen ja sen kehittämien teorioiden ja käsitteiden avulla. Hyvän vertailukohteen tarjoaa tässä kirjallisuudentutkimus, jonka tutkimussuuntausten uskomaton paljous tekee mahdottomaksi puhua siitä ja harjoittaa sitä yhtenäisenä kirjallisuustieteellisenä järjestelmänä, yhtenä kirjallisuustieteenä. Kirjallisuudenopetus on nähdäkseni vielä moninkertaisesti enemmän monimääräytynyttä (eli siihen vaikuttavat vielä useammat seikat) kuin kirjallisuudentutkimus, joten sitä koskevan yhtenäisen kirjallisuusdidaktiikka-tieteen olettaminen on vain harha, johon meillä opettajilla on taipumus langeta, koska usein ajattelemme, että sellaisen olemassaolo tekisi työstämme arvokkaampaa, "tieteellisempää". Kirjallisuudenopetus on niin arvokas asia mielestäni juuri siksi, että se vaatii harjoittajaltaan niin monen alan tuntemusta ja soveltamiskykyä yhtaikaa, ei siksi, että se kaikkinensa olisi johdettavissa jostain yhdestä totalitaarisesta kirjallisuusdidaktisesta järjestelmästä.
Kokonaan toinen asia on, että eri näkökulmien valossa tutkittu empiirinen aineisto ohjaa yleensä tekemään jonkinasteisia yleistyksiä. Pisimmälle viety yleistys, johon empiirisen aineistoni ohjaamana tutkimuksessani uskaltauduin, oli päätelmä ns. integratiivisesta lukemiskulttuurista (vs. esteettinen lukemiskulttuuri), joka näyttää aineistoni perusteella varsin laajalti ohjanneen meikäläistä kirjallisuudenopetusta. Pidän varsin kummallisena sitä, ettet arvostelussasi edes mainitse integratiivista lukemiskulttuuria etkä sen pohjalta nousevaa temaattista kirjallisuudenopetusta, vaikka ymmärtääkseni itse olet työssäsi toteuttanut niitä sangen menestyksekkäästi. Tältä kannalta Boel Englundin Ruotsin lukioiden kirjallisuudenopetusta koskevat tutkimustulokset eivät ole mikään "kiinnostava uusi näkökulma aineistoon", kuten sanot, vaan jo oman aineistoni pohjalta toteamani ilmiön tärkeä rinnakkaisilmiö.

Vielä pari pienempää seikkaa. En ole johtanut ulkomaisen kirjallisuuden lisääntymistä koululukemistossa "suoraan EU:n luomasta tarpeesta”, kuten väität. Ulkomaiset teokset olivat nousseet tasoihin kotimaisten kanssa jo vuoden 1979 kyselyssä (s. 73, taulukko 14), mikä selittyy kirjallisuudenopetuksen suurella 1960-luvun murroksella ja siihen vaikuttaneilla monilla syillä (esim. s. 24, 32). Maailmankirjallisuuden mestarinovelleja ei ole Jorma Ojaharjun vaan Aulis Ojajärven toimittama.

\section{Juha Rikama}




\section{Topelius' Konungens handske - how history is (re)written}

A historical novel often discusses the nature of history, both overtly and covertly. In Zacharias Topelius' Konungens handske (1863) there is a foreword and an afterword, in which the nature of history is explicated. The narrator emphasizes the meaning of emotions in history, but rather on a collective than individual level. Providence has an important role in history, and nations are seen as actors in the predetermined progress of events.

The novel depicts autumn 1788: the war between Sweden and Russia, and a conspiracy by several officers called Anjala League. The Anjala men opposed the war, and some aimed at independence of Finland. The questions of loyalty and nationality are provoked in the novel because of the subject matter as well as several contextual matters: During the time depicted, Finland was part of Sweden, during the time of writing an autonomous grand duchy of Russia. Besides that, the novel was originally published as a serial in a Swedish newspaper, a Swedish audience in mind.

History and nationality intertwine in the novel. The philosophy of history combined with the narrative advocate for a new interpretation of history and for the legitimacy of the Finnish autonomy.

\section{Mari Hatavara}

\section{"The wide gap between us and you".}

The Poor and the Rich in Pentti

Haanpää's Novel Isännät ja isäntien varjot (Masters and Masters'

Shadows)

The novel Isännät ja isäntien varjot (1935) by Pentti Haanpää contains a significant amount of allusions to the Bible. This fact has been taken note of in earlier study, and the novel has been proved to have as its intertexts a few very well known Old Testament stories: The story of Esau and Jacob, the story of the journey to the Promised Land, The book of Job and a few others.

This article shows that one interesting intertext has not been discovered in earlier studies: The story of a rich man, poor Lazarus and Abraham in Luke's gospel (Luke 16: 19-31). Perceived intertext arranges and at the same time enriches in a new way the thematic field of the novel. Through the intertext the gap between the rich and the poor becomes even more noticeable. At the same time, the social criticism in the novel appears sharper than ever.

The connection with the story in Luke's gospel deepens also the existential level of the novel as the messages from another world or another reality troubles the hero of the novel. In the world of the novel, justice does not win, but it gives a hint that in the invisible world even the poor can gain justice.

Juhani Sipilä

Translated by Sini Lehtinen 


\section{Hannu Salama's V style Metafictivity as a factor in remodeling the realistic no- vel in the 1970's}

This article examines Hannu Salama's novels Siinä näkijä missä tekijä (1972) and Kosti Herhiläisen perunkirjoitus (1976) as realistic and metafictive novels. The main argument is that metafictive devices do not necessarily lead to exclusion of mimesis and realism, as the most categorical views suggest, but they can become a part of the remodeled realistic novel. According to Patricia Waugh (1985) fiction that is based on realistic conventions but at the same time lays them bare critically and resourcefully can be called "new realism".

In Salama's novels metafiction is manifested primarily in explicit and thematized diegetic form, "mimesis of the process" (Hutcheon 1984). In Salama's novels it is used mainly to question truthfulness and validity of (ideological) grand narratives and traditional conventions of social (working-class) realism. This is connected with postmodern changes in society, culture and ways of thinking but not with postmodernism.

Idea of metafiction as a part of realistic novel suggests also that literary realism is a more flexible mode than most traditional and poststructuralist theories propose. But reconsidered from Bertolt Brecht's point of view realistic writing turns out to be constantly updating criti- cal practice with no predestined form. It can also include brechtian alienation effects $(V$-effekt) which actually are metafictive elements. And if language is viewed as both referential (maintaining "will to reference") and (self-)reflexive, like Mihail Bakhtin suggested, metafictive features do not mean incompatibility with realism at all.

\section{Milla Peltonen}

\section{Prosaic Stage - On the theatre of Walter Benjamin}

Article asks the role and signification of theatre in the thought of Walter Benjamin by comparing his essays on Brecht's epical theatre from the 1930's with his doctoral thesis of 1919 on the literary theory in the Romanticism of Iena. The approach makes possible to present a more general question concerning the reasons why theatre is reinvented during the past century precisely as a scenic art and as an art of director. In his thesis, Benjamin defends an idea of a different kind of Romanticism which, against the prevailing bourgeois ideas, is politically revolutionary and "sober" by its expression. By assuming novel as the paradigm of work of art, the romantic literary theory accomplishes itself in the idea of "poetry as prose". Benjamin's own "Brechtian turn", as well as the epical theatre he analyses, can be explained as a consequent continuati- 
on and critical explication of the former "prosaic turn". In the "gesture" (Geste), which according to Brecht constitutes the basic element of scenic representation, can be recognized the same "estranging" and "retarding" dynamics and structure as in the "connexions" (Zusammenhang) of the romantic prose. Correspondingly, the "scenic turn" in modern theatre motivates itself by a more general historical change which, still today, continues to dislocate the modes of representation and social existence.

\section{Esa Kirkkopelto}

\section{Että hän \\ muistais saman}

Elina Hirvonen

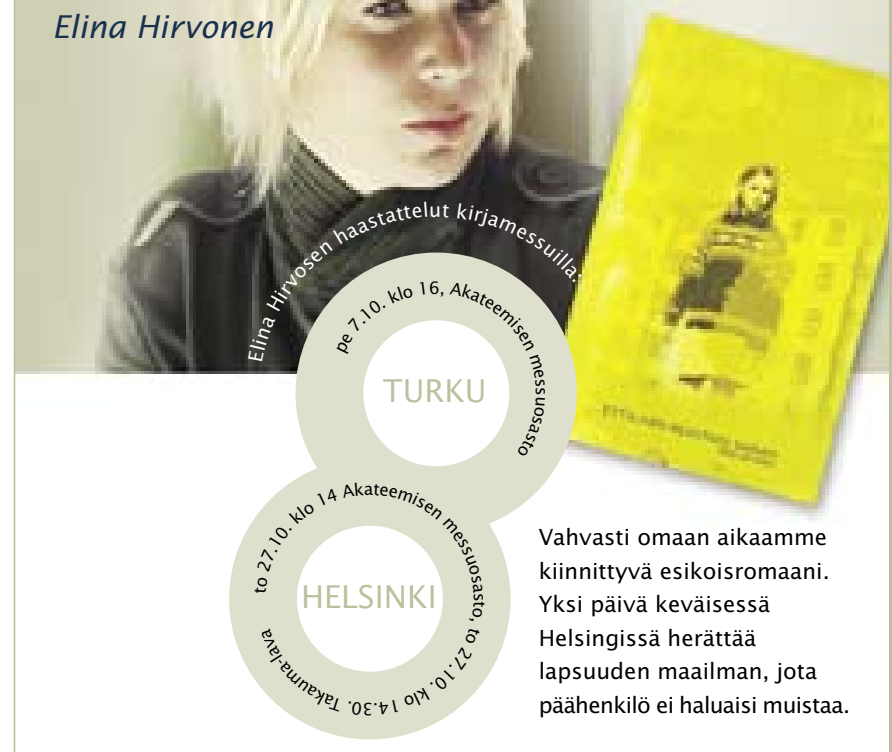




\section{KULTTUURIVIHKOT

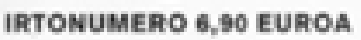 \\ NUMERO $6 / 2005$}

RUOTSIN RUOSKA

JAN MYRDAL ISKEE YHÄ VASTAKARVAAN

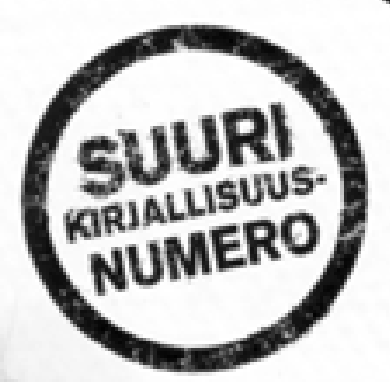

Jean-Luc GODARD

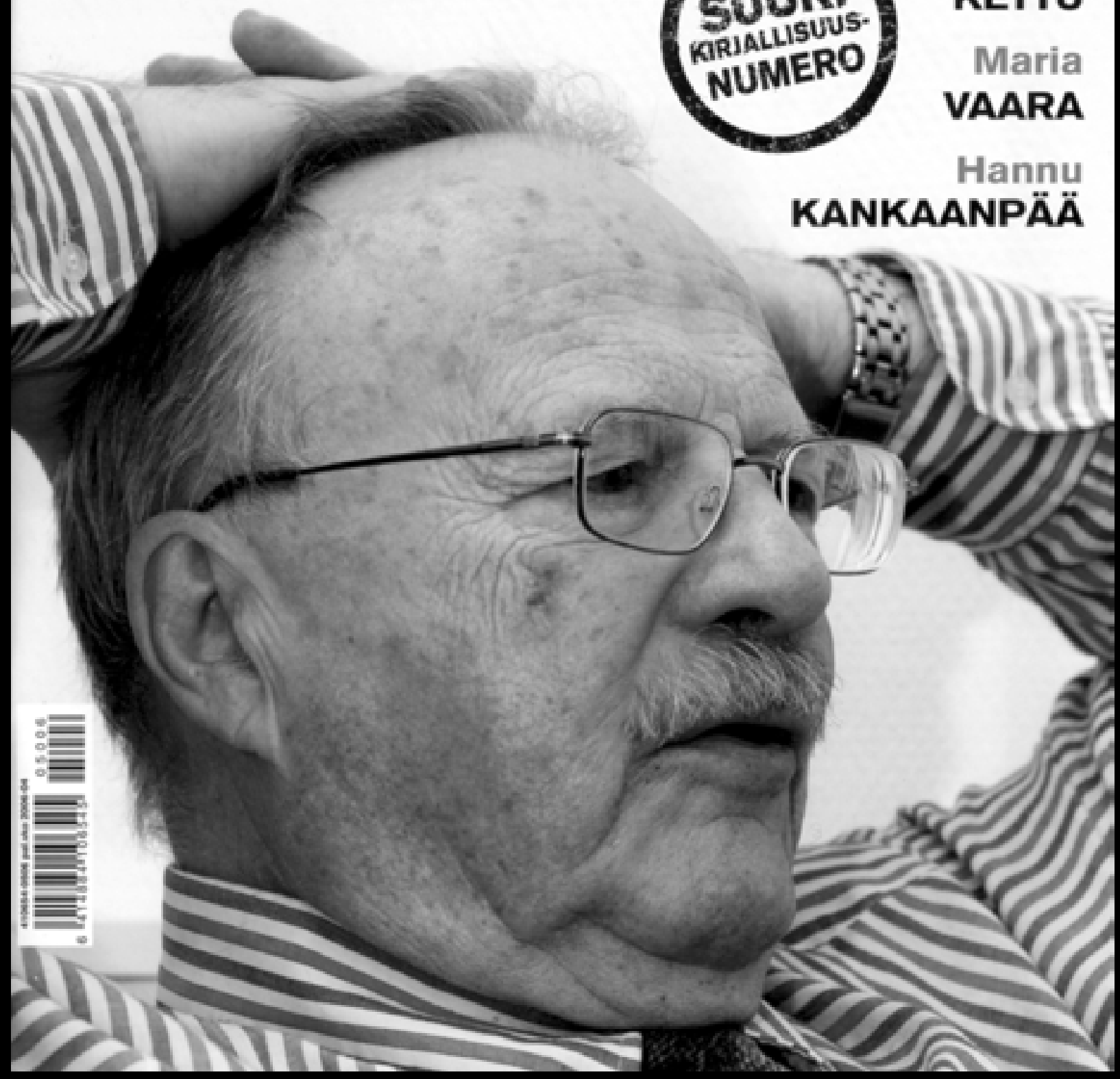

\section{Hannu KANKAANPÄÄ}

Katja KETTU

Maria VAARA
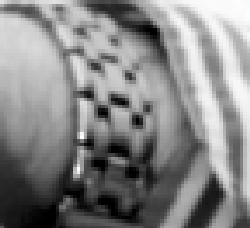

ate

Hyvissä Lehtipisteissä. 6,90 euroa. 


\section{Kirjoitusehdotuksia Avai- meen}

Kirjallisuudentutkimuksen aikakauslehti Avain ottaa vastaan jatkuvasti ehdotuksia artikkelien lisäksi myös puheenvuoroiksi, keskusteluksi, arvosteluiksi ja muiksi kirjoituksiksi. Kirjoitusten julkaisemisesta päättävät kulloisenkin lehden päätoimittajat.

Ehdotuksia voi lähettää sähköpostitse lehden toimitussihteerille Heta Muuriselle osoitteeseen:

heta.muurinen@helsinki.fi.

\section{Ohjeita kirjoittajille}

Kirjoitukset osoitetaan joko suoraan lehden toimittajille tai toimitussihteerille. Mukaan tulee liittää kirjoittajan koko nimi, lehdessä käytettävä(t) titteli(t) sekä joko yliopisto tai paikkakunta, sähköpostiosoite, puhelinnumero ja postiosoite, johon haluaa lehden lähetettävän.

Asiantuntijat arvioivat artikkelit referee-menettelyn mukaisesti. Kirjoitukset laaditaan ilman tekstinkäsittelyohjelmien asettelutoimintoja (esim. tavutus ja tasaus).

Teksti lähetetään PC-yhteensopivana, mieluiten rtf-muotoon tallennettuna tiedostona.

Tekstejä ei palauteta kirjoittajille, kuvat palautetaan.

\section{Artikkelit}

Artikkeleiden ohjepituus on n. 20000 - 40000 merkkiä välilyönteineen. Kritiikkien suositusmitta on enintään 5000 merkkiä välilyönteineen.

Teosten nimet kursivoidaan. Artikkelien otsikot laitetaan lainausmerkkeihin (lähdeluetteloon ilman lainausmerkkejä). Sitaatit suomennetaan. Käsitteet, joita halutaan painottaa, kursivoidaan. Tummennusta ja alleviivausta ei käytetä.

Artikkelin kirjoittajat laativat lyhyet (n. 1500 merkkiä välilyönteineen) englanninkieliset abstraktit artikkeleistaan.

\section{Viitteiden käytöstä}

Lähdeviitteen tiedot laitetaan sisäviitteisiin. Sisäviitteessä käytetään vuosilukua, joka on kirjoittajan käyttämän teoksen ilmestymisvuosi. Alkuperäinen ilmestymisvuosi mainitaan lähdeluettelossa.

Loppuviitteitä käytetään, jos halutaan tehdä lisäyksiä, kommentteja yms., joita ei ole tarpeen kirjoittaa varsinaiseen tekstiin.

Teoksista voidaan käyttää myös lyhenteitä viitteissä, jos se on tekstin kannalta järkevää, mutta viitteiden tulee olla helposti ymmärrettäviä ja johdonmukaisia.

\section{Lähdeluettelosta}

Lähdeluettelossa mainitaan tiedot seuraavassa järjestyksessä: tekijä, ilmestymisvuosi / ja alkuperäinen ilmestymisvuosi), teoksen nimi, toimittaja, kääntäjä, julkaisusarja, kustantajan kotipaikka/kotipaikat ja kustantamo. Lisäksi kokoomateosten ja tieteellisten lehtien artikkelien kohdalla mainitaan sivunumerot. 